\begin{tabular}{|c|c|c|c|c|c|c|}
\hline \multirow{4}{*}{ Impact Factor: } & ISRA (India) & $=3.117$ & SIS (USA) & $=0.912$ & ICV (Poland) & $=6.630$ \\
\hline & ISI (Dubai, UAE & $=0.829$ & РИНЦ (Russia & $=0.156$ & PIF (India) & $=1.940$ \\
\hline & GIF (Australia) & $=0.564$ & ESJI (KZ) & $=5.015$ & IBI (India) & $=4.260$ \\
\hline & JIF & $=1.500$ & SJIF (Morocco & $=5.667$ & & \\
\hline
\end{tabular}

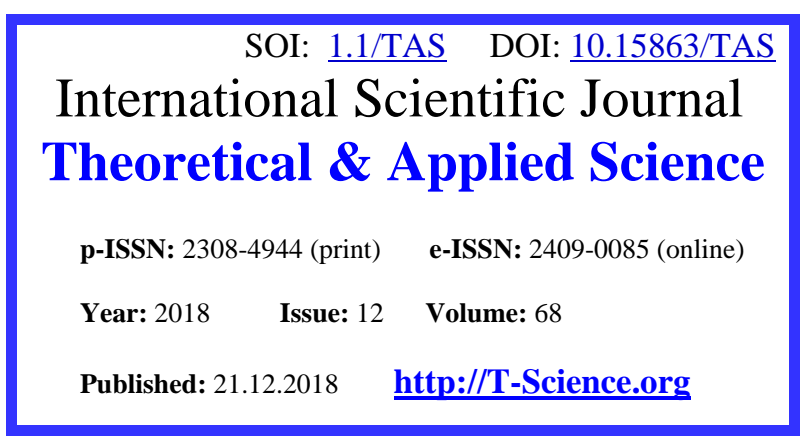

SECTION 31. Economic research, finance, innovation, risk management.

International Scientific Journal Theoretical \& Applied Science

p-ISSN: 2308-4944 (print) e-ISSN: 2409-0085 (online)

Published: $21.12 .2018 \quad$ http://T-Science.org
QR - Issue

QR - Article
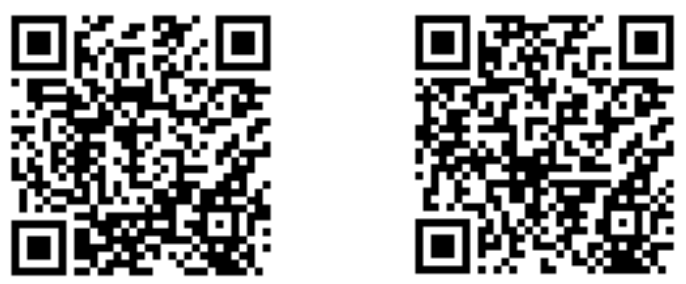

Elena Viktorovna Bergal Candidate of Economic Sciences, Associate Professor,

Kuban State University Russia, Krasnodar

Alina Viktorovna Grechko Student,

Kuban State University Russia, Krasnodar

\title{
FEATURES OF CALCULATION AND PAYMENT OF LAND TAX BY BUDGET ORGANIZATIONS
}

Abstract: The article discusses the features of the calculation and payment of land tax by budget organizations, based on the cadastral value. Authors revealed the procedure for determining the tax base and the application of tax rates, especially the formation of the cadastral value of land, the system of tax incentives for public institutions. In the course of the study, the range of problems that budget organizations face when paying land tax is clarified, and ways to solve them that reduce the tax burden are identified. The main one is the optimization of the tax base in the absence of tax benefits.

Key words: land tax, tax accounting, budgetary institutions, cadastral value, tax base, tax rate, tax benefits, state cadastral valuation, tax optimization.

Language: Russian

Citation: Bergal, E. V., \& Grechko, A. V. (2018). Features of calculation and payment of land tax by budget organizations. ISJ Theoretical \& Applied Science, 12 (68), 137-140.

Soi: http://s-o-i.org/1.1/TAS-12-68-25 Doi: crossef https://dx.doi.org/10.15863/TAS.2018.12.68.25

\section{ОСОБЕННОСТИ ИСЧИСЛЕНИЯ И УПЛАТЫ ЗЕМЕЛЬНОГО НАЛОГА БЮДЖЕТНЫМИ ОРГАНИЗАЦИЯМИ}

Аннотация: В статье рассмотрены особенности исчисления и уплаты бюджетными организациями земельного налога, исходя из кадастровой стоимости. Авторами освещен порядок определения налоговой базы и применения ставок налога, особенности формирования кадастровой стоимости земельных участков, система налоговых льгот для бюджетных учреждений. В прочессе исследования уточнен круг проблем, с которым сталкиваются бюджетные организации при уплате земельного налога, и определены пути их решения, позволяющче снизить налоговую нагрузку. Основной из них - оптимизация налоговой базы при отсутствии налоговых льгот.

Ключевые слова: земельный налог, налоговый учет, бюджетные учреждения, кадастровая стоимость, налоговая база, налоговая ставка, налоговые льготы, государственная кадастровая оценка, оптимизация налогообложения.

\section{Introduction}

Организации государственного (муниципального) сектора экономики - казенные, бюджетные автономные учреждения для выполнения возложенных на них задач и функций наделяются недвижимым и движимым имуществом на праве оперативного управления и земельными участками на праве постоянного (бессрочного) пользования или на праве аренды. Земельные участки, застроенные или свободные, становятся объектами налогообложения, так как использование земли в Российской Федерации является платным, в силу статьи 65 Земельного кодекса Российской Федерации. Как следствие, государственные (муниципальные) организации становятся плательщиками земельного налога. В 


\begin{tabular}{|c|c|c|c|c|c|c|}
\hline \multirow{4}{*}{ Impact Factor: } & ISRA (India) & $=3.117$ & SIS (USA) & $=0.912$ & ICV (Poland) & $=6.630$ \\
\hline & ISI (Dubai, UAE & $=0.829$ & РИНЦ (Russia & $=0.156$ & PIF (India) & $=1.940$ \\
\hline & GIF (Australia) & $=0.564$ & ESJI (KZ) & $=5.015$ & IBI (India) & $=4.260$ \\
\hline & JIF & $=1.500$ & SJIF (Moroccc & $=5.667$ & & \\
\hline
\end{tabular}

соответствии с действующим законодательством бюджетные организации становятся полноценными, самостоятельными участниками налоговых правоотношений, обладающими правами и обязанностями, несущими ответственность за нарушение налогового законодательства [4, с. 23].

Земельный налог в установленном порядке может уплачиваться из двух источников: за счет средств, полученных из бюджета на выполнение государственного (муниципального) задания; за счет доходов, полученных от предпринимательской и иной приносящей доход деятельности [5, с. 219].

\section{Materials and Methods}

Налоговой базой для уплаты земельного налога является кадастровая стоимость земельного участка, которая определяется по результатам государственной кадастровой оценки земель, которая проводится не чаще чем один раз в течение трех лет (исключением являются города федерального значения, в них процедура проводится не чаще чем один раз в течение двух лет) и не реже, чем один раз в течение пяти лет с последней оценки. Органы, занимающиеся оценкой кадастровой стоимости и государственной регистрацией прав на земельные участки, уведомляют налоговые органы и передают им сведения о земельных участках и их владельцах [8, с. 146]. С января 2019 года будут действовать следующие правила изменения кадастровой стоимости и ее использования в качестве налоговой базы.

Так, изменение кадастровой стоимости участка возможно в силу преобразования характеристик земли учитывается при определении налоговой базы с момента внесения в Единый государственный реестр недвижимости (ЕГРН) сведений, являющихся основанием для определения кадастровой стоимости. Изменение кадастровой стоимости земельного участка осуществляется вследствие исправления технической ошибки в сведениях реестра, сведения о преобразованной кадастровой стоимости, внесенные в ЕГРН, начинают использоваться при определении налоговой базы начиная с даты начала применения для целей налогообложения данных об изменяемой кадастровой стоимости. Другое условие, изменении кадастровой стоимости земли на основании установления его рыночной стоимости сведения о новой стоимости, внесенные в реестр недвижимости, учитываются при определении налоговой базы начиная с даты начала применения для целей налогообложения кадастровой стоимости, являющейся предметом оспаривания [6].

Земельный

налог

является бюджетообразующим для муниципальных образования и вводится решением Совета депутатов муниципального образования. Муниципальных органы власти определяют величину налоговых ставок самостоятельно, в пределах, установленных ст. 394 НК РФ (от 0,3 процента до 1,5 процента), определяют также порядок и сроки уплаты налога. Налогоплательщик самостоятельно рассчитывается земельный налог как произведение налоговой базы (кадастровой стоимости земельного участка) и ставки земельного налога, установленной муниципальным нормативно-правовым актом.

Сумма земельного налога, подлежащего уплате в соответствии с НК РФ, определяется как разница между суммой налога, исчисленной по истечении налогового периода, и суммами подлежащих уплате в течение налогового периода авансовых платежей по данному налогу. Полное погашение всей суммы налога происходит после завершения отчетного года: по итогам налогового периода, с учетом всех авансовых платежей [9, с. 17].

Налоговым периодом по земельному налогу выступает календарный год, отчетными периодами для бюджетных учреждений являются первый, второй и третий квартал календарного года, срок уплаты налога не может быть ранее 1 февраля года, следующего за предыдущим налоговым периодом. Если последний день срока сдачи декларации придется на выходной или нерабочий праздничный день, то сдать ее можно будет в ближайший следующий за ним рабочий день. Исчисление авансовых платежей осуществляется в течение налогового периода не позже крайнего числа месяца, следующего за прошедшим периодом. Уплата суммы налога и авансовых платежей осуществляется в бюджет по месту нахождения земельного участка, являющегося объектом налогообложения. Особенность данной формы декларации по земельному налогу заключается в том, что если на протяжении года происходили изменения его кадастровой оценки из-за смены категории земли, вида разрешенного использования или изменения площади, то по одному участку необходимо заполнять несколько разделов 2 «Расчет налоговой базы и суммы земельного налога». Предоставление налоговой декларации по земельному налогу бюджетным учреждением происходит после окончания налогового периода в орган налоговой службы по месту нахождения участка. Бюджетные организации, которые уплачивают авансовые платежи, после окончания налогового периода представляют в ФНС расчет по авансовым платежам.

Для организаций государственного (муниципального) сектора Налоговый кодекс 


\begin{tabular}{|c|c|c|c|c|c|c|}
\hline \multirow{4}{*}{ Impact Factor: } & ISRA (India) & $=3.117$ & SIS (USA) & $=0.912$ & ICV (Poland) & $=6.630$ \\
\hline & ISI (Dubai, UAE & $=0.829$ & РИНЦ (Russia) & $=0.156$ & PIF (India) & $=1.940$ \\
\hline & GIF (Australia) & $=0.564$ & ESJI (KZ) & $=\mathbf{5 . 0 1 5}$ & IBI (India) & $=4.260$ \\
\hline & JIF & $=1.500$ & SJIF (Morocco) & $=5.667$ & & \\
\hline
\end{tabular}

устанавливает ограниченный перечень льгот. Освобождаются от уплаты земельного налога организации и учреждения уголовноисполнительной системы Министерства юстиции Российской Федерации, использующие земельные участки, предоставленные для непосредственного выполнения возложенных на них функций. Не платят земельный налог и управляющие компании, расположенные на территории инновационного центра «Сколково», использующие земельные участки, входящие в состав территории цента, и предоставленных для непосредственного выполнения возложенных на эти организации функций.

Помимо вышеуказанных, муниципальные органы власти имеют право самостоятельно устанавливать льготы по земельному налогу для некоторых категорий плательщиков. Рассмотрим примеры льгот по земельному налогу на территории муниципального образования для бюджетных организаций, предусмотренных в муниципальных правовых актах. Например, в муниципальном образовании город Владикавказ Республики Северная Осетия-Алания льгота в размере $100 \%$ предоставлена муниципальным учреждениям образования, здравоохранения, культуры, социального обеспечения, физической культуры и спорта. В муниципальном образовании Нижний Новгород льгота в виде снижения ставки земельного налога на 33,3\% предоставлена муниципальным учреждениям в отношении земель под объектами образования, здравоохранения, социального обеспечения, физической культуры, спорта, культуры и искусства. Для получения льготы в виде полного или частичного освобождения от уплаты земельного налога бюджетное учреждение должно представит документы, подтверждающие такое право, в налоговый орган по месту нахождения земельного участка. Кроме того, если у бюджетного учреждения на праве хозяйственного ведения или оперативного управления находятся земли, изъятые из оборота, к таким землям также применяется льгота по земельному налогу. К таким землям относятся участки, занятые метеорологическими станциями или предоставленные для обеспечения безопасности [1]. В Письме Минфина РФ №0305-04-02/24445 от 24 апреля 2017 года, поясняющем порядок определения налоговой базы по земельному налогу, говорится, что на данный момент единственным достоверным источником, сообщающим информацию об объектах недвижимости, является Единый государственный реестр недвижимости, помимо этого упоминается, что определение налоговой базы осуществляется бюджетными учреждениями самостоятельно на основании сведений реестра [2].
Современное законодательство, формируя правовую основу для исчисления и уплаты земельного налога бюджетного учреждения, порождает ряд проблем.

Во-первых, при определении суммы земельного налога отсутствует учет доходности земли, в результате не выполняется принцип справедливости системы налогообложения, который подразумевает, что каждый налогоплательщик должен платить налог в соответствии со своим достатком.

Во-вторых, кадастровая стоимость земельного участка превышает рыночную стоимость.

В-третьи, отсутствуют четкие характеристики объектов, указанных в документах Росреестра, используемых при установлении кадастровой стоимости земли. По факту осуществляется массовый способ определения кадастровой стоимости, не дающий объективный результат [10, с. 68-70].

Пути решения обозначенных проблем носят дискуссионный характер и заключаются в следующем. Полагаем, что учет доходов налогоплательщика от использования земли позволил бы сделать налогообложение более справедливым и позволил увеличить доходы местного бюджета, например, за счет владельцев высокодоходных земельных участков.

Другой путь - это возможность для бюджетного учреждения оспорить результаты государственной кадастровой оценки участка и сократить расходы на уплату налога. Процесс оспаривания результатов может осуществляться в суде и в созданных при территориальных органах Росреестра комиссиях [7, с. 129]. Однако потребуется вмешательство в данный процесс независимых оценщиков, что повлечет существенные дополнительные затраты. Экспертиза, определяющая справедливую рыночную стоимость земли, является платной, а сам процесс пересмотра и корректировки стоимости занимает достаточно продолжительное время. При оспаривании кадастровой стоимости могут предъявляться следующие требования: установление рыночной стоимости в отношении объекта; изменение стоимости, связанное с обнаружением сведений, не соответствующих действительности, например, в связи с технической ошибкой или кадастровой ошибкой; оспаривание действий и решений комиссии, установившей данную стоимость.

Решение проблемы

отсутствия индивидуальных характеристик объектов при государственной кадастровой оценке возможно путем формирования базы критериев, увеличивающих или уменьшающих стоимость земли. Приравнивание кадастровой оценки к рыночной стоимости объекта является 


\begin{tabular}{|c|c|c|c|c|c|c|}
\hline \multirow{4}{*}{ Impact Factor: } & ISRA (India) & $=3.117$ & SIS (USA) & $=0.912$ & ICV (Poland) & $=6.630$ \\
\hline & ISI (Dubai, UAE & $=0.829$ & РИНЦ (Russia) & $=0.156$ & PIF (India) & $=1.940$ \\
\hline & GIF (Australia) & $=0.564$ & ESJI (KZ) & $=\mathbf{5 . 0 1 5}$ & IBI (India) & $=4.260$ \\
\hline & JIF & $=1.500$ & SJIF (Morocco) & $=5.667$ & & \\
\hline
\end{tabular}

наилучшим вариантом для справедливого налогообложения в рамках всей страны. При этом проблематично сделать массовую оценку участков индивидуальной, так как справедливая цена определяется на основе ряда индивидуализированных показателей, которые трудно учитывать в рамках общегосударственной оценки. Несмотря на это, процесс сближения кадастровой и рыночных оценок стоимости участков уже запущен.

\section{Conclusion}

В завершении следует отметить, что особенности исчисления и уплаты земельного налога бюджетными организациями являются специфическими в силу их особого положения, направленного на выполнение социально значимых функций и задач, финансируемых из бюджета. Муниципальные образования самостоятельно определяют налоговые льготы и налоговые ставки по земельному налогу, в силу чего происходит своеобразная дифференциация положения бюджетных организаций, расположенных в пределах разных муниципалитетов. Данный факт порождает необходимость в оптимизации налоговых льгот для тех учреждений, которые уплачивают налог в полном размере или частично [3, с. 140]. Сложившаяся ситуация свидетельствует о необходимости создания оптимальных и равномерных условия обложения бюджетных организаций земельным налогом на территориях муниципальных образований разных регионов.

\section{References:}

1. (2000). The tax code of the Russian Federation (part two). Federal law of 05.08.2000 No. 117FL. Retrieved November 25, 2018, from http://www.consultant.ru/document/cons_doc_ LAW_28165/

2. (2017). Letter of the Federal Tax Service of Russia dated April 26, 2017 No. BS-4-21 / 7937

"On the procedure for determining the tax base for land tax" (together with the Letter of the Ministry of Finance of the Russian Federation No. 03-05-04-02 / 24445 of April 24, 2017). Retrieved November 25, 2018, from http://www.consultant.ru/document/cons doc LAW 216384/

3. Agafonova, O. V., \& Zavalniuk, A. V. (2018). Analysis of the cadastral and market value of a land plot in order to change the land tax using an econometric approach to valuation. Bulletin of the Novosibirsk State Agrarian University. T.1 (46), 136-141.

4. Dementieva, N. M. (2014). Accounting for taxes in budgetary institutions. Accounting in budget and non-profit organizations. T.9 (345), 22-27.

5. Ladyzhenskaya, T. P., \& Nikulina, A. I. (2017). Features of taxation of state, budget and autonomous institutions. Economy and society. T.10 (41), 215-221.

6. (2018). Official website of the Federal Tax Service. Retrieved November 28, 2018, from http://www.nalog.ru

7. Pisarev, D. I. (2016). Calculation of land tax when the cadastral value of land changes. Accounting. T.8, 129-130.

8. Saifulova, L. G. (2016). Calculation of property taxes when changing the cadastral value. Bulletin of the Tga University. V.N. Tatishcheva. T.2, 145-153.

9. Semenikhin, V. V. (2016). Land tax in budget institutions. Non-profit organizations in Russia. T.5, 14-21.

10. Surovtsov, M. M., Gubadeeva, N. M., \& Klesova, A. Y. (2017). Land tax: problems of calculating the cadastral value of land. Corporate economy, T.2 (10), 66-72. 